\title{
Organizma Metaforunun Eğitim Örgütlerine Yansımaları
}

\section{Dr. Sevda Katıtaş ${ }^{1 *}$}

Geliș tarihi: 07.10.2019

Kabul tarihi: 05.11.2019

\section{Atıf bilgisi:}

IBAD Sosyal Bilimler Dergisi

Sayı: 5 Sayfa: $329-342$

Yıl: 2019 Dönem: Güz

This article was checked by iThenticate. Similarity Index $2 \%$

1 Milli Eğitim Bakanlığı, Türkiye, sasevda@gmail.com,

ORCID ID 0000-0003-3512-6677

* Sorumlu yazar
ÖZ

Örgütlere farklı açılardan bakmamızı sağlayan metaforlar, bizlere örgütleri yapı ve işleyiş bakımından derinlemesine inceleme firsatı vermektedir. $\mathrm{Bu}$ bağlamda, örgütün doğasını açıklamada en yaygın kullanılan metaforlardan biri organizma metaforudur. Organizma metaforu ile örgütler organizmalara benzetilmektedir. Organizma metaforu örgütün tıpkı bir organizmada olduğu gibi doğumdan ölüme kadar geçen süreçte değişen çevresel koşullara nasıl uyum sağladığını anlamamıza katk1 sağlamaktadır. Bu çalışmada, öncelikle organizma metaforu kapsamındaki yönetim kuramları incelenmiştir. Daha sonra organizma metaforunun güçlü ve zayıf yönleri ele alınarak bu metaforun eğitim örgütlerine yansıması tartışılmıştır.

Anahtar Kelimeler: Metafor, Organizma Metaforu, Eğitim Örgütleri 


\section{Reflections of Organizm Metaphor to Educational Organizations}

\section{Dr. Sevda Katıtaş ${ }^{1 *}$}

First received: 07.10.2019

Accepted: 05.11.2019

\section{Citation:}

IBAD Journal of Social Sciences

Issue: 5

Pages: $329-342$

Year: 2019

Session: Fall

This article was checked by iThenticate. Similarity Index $2 \%$

1 The Ministry of National Education, Turkey,sasevda@gmail.com,

ORCID ID 0000-0003-3512-6677

* Corresponding Author

\begin{abstract}
Metaphors that enable us to look at the organizations from different angles give us an opportunity to explore in depth the structure and functioning of organizations. In this context, one of the most widely used metaphor for describing the nature of organization is the organism. With the organism metaphor, organizations are likened to organism. The organism metaphor contributes to our understanding of how the organization adapts to changing environmental conditions, from birth to death, just as it is in the organism. In this study, firstly the management theories within the scope of the organism metaphor have been examined. Subsequently, the reflection of this metaphor on education organizations has been discussed, taking into account the strengths and weaknesses of the organism metaphor
\end{abstract}

Keywords: Metaphor, Organism Metaphor, Educational Organizations 


\section{GİRIŞ}

Tarihsel süreç içerisinde bilim adamları örgütleri yapı ve işleyişleri bakımından inceleyerek anlamaya ve açıklamaya çalışmışlardır. Günümüzde gerek örgütü oluşturan bireylerde gözlemlenen gerekse örgütün yönetsel süreçlerinde ve çevresel koşullarında yaşanan değişme ve gelişmelerle birlikte örgütler de sürekli olarak gelişmektedir. Bireysel ve örgütsel düzeyde yaşanan bu gelişmeler, yeni bilgi ve becerilere ihtiyacın artmasına neden olmakla birlikte örgütlerin yapı ve işleyiş açısından anlaşılmasını zorlaştırmaktadır. $\mathrm{Bu}$ bağlamda, örgütleri daha iyi analiz etme ve anlamada metaforlara ihtiyaç duyulmaktadır.

Lakoff ve Johnson'a (2005) göre metafor en genel anlamıyla bir şeyi başka bir kavram veya nesneye göre anlamak ve deneyimlemektir. Metafor kavramı, bilinmeyeni bilinene iletmek amacıyla açılamada kullanılan bir söz sanatı olarak da ifade edilmektedir (Mutlu, 2004). Metaforlar sadece anlatımı süslemeye yönelik bir söz sanatından ibaret değildir. Metafor aslında genel anlamda dünyayı anlamamıza yarayan bir düşünme ve görme şeklini belirtmektedir (Morgan, 1998). Balcı'ya (1999) göre, metaforların bize görünenlerin daha derinlerindeki bilgileri sunmaları ve soyut kavramları somutlaştırarak anlamlandırma sürecimizi hızlandırmaları önemli rolleri arasında bulunmaktadır.

Örgüt ve yönetim kuramları da örgütleri ayırt edici biçimde görmemizi, anlamamızı ve yönetmemizi sağlayan metaforlara dayanmaktadır. Örgüte ilişkin metaforlar, örgütün mevcut durumu hakkında bilgi vermekle birlikte örgütün gelecekte ne olması ve nasıl yönetilmesi gerektiğine dair ipuçlarını da barındırmaktadır. Dolayısıyla metaforlar örgütlere farklı açılardan bakmayı sağlamaktadır (Şişman, 2011). Örgütün doğasını açıklamada yararlanılan metaforlardan en yaygın olanları makine ve organizma metaforları olup bunları sırasıyla beyin, kültür, politika, psişik hapishane, akış ve dönüşüm ile tahakküm aracı metaforları takip etmektedir (Morgan, 1998). Bu çalışmada organizma metaforunun dayandığı yönetim kuramları incelenerek bu metaforun eğitim örgütleri bağlamında değerlendirilmesi amaçlanmıştır. $\mathrm{Bu}$ amaç doğrultusunda öncelikle organizma metaforu tanımlanmış ve organizma metaforunun dayandığı kuramlar incelenmiştir. Daha sonra organizma metaforunun güçlü ve zayıf yönleri vurgulanarak eğitim örgütleri bağlamında organizma metaforu değerlendirilmiştir.

\section{ORGANIZMA METAFORU VE ORGANIZMA METAFORUNUN DAYANDIĞI KURAMLAR}

Klasik örgüt kuramını oluşturan ilkeler genellikle örgüt yapısının en iyi hale nasıl getirilebileceği problemi üzerinde durmaktadır. Bu ilkelerin bütün örgütler için geçerli olduğu kabul edilmektedir. Bunun sonucu olarak da "bürokratik" ve daha genel ifade ile "mekanik" olarak adlandırılan örgütler ortaya çıkmaktadır. Mekanik örgütler insan ögesine özel bir önem vermemektedir. Bu yaklaşıma göre, insan ögeleri dışındaki ögelerin belirlenen ilkelere göre birleştirilmesiyle yapı oluşturulmakta ve insanın bu yapı içerisinde bir makine gibi davranacağı varsayılmaktadır (Koçel, 2005).

Mekanik örgüt anlayışının eksiklikleri ve beraberinde getirdiği sorunları, zamanla örgüt kuramcılarının mekanik yaklaşımdan uzaklaşarak kaynak olarak biyolojiye yönelmelerine yol açmış ve örgütler organizmaya benzetilmiştir (Morgan, 1998). Organizma metaforuna göre örgütler, hayatta kalmak için canlılar gibi çevresine bağımlıdırlar. Canlılar çevrelerinden yiyecek ve barınak sağlarken; örgütler de çevrelerinden bilgi, para, işçi ve hammadde sağlamaktadırlar. Bunlar bir örgütün yaşaması için gerekli olan girdilerdir (Hatch, 1997; Akt. Nayır, 2008). Bu açıdan bakıldığında organizma metaforunda, örgütün tıpkı canlı bir varlık olarak tasarlandığı görülmektedir. Nasıl ki canlı varlıkların yaşayabilmesi için uygun çevre ve koşullar gerekiyorsa örgütler de yaşamlarını sürdürebilme aşamasında uygun bir çevrede doğan (başlangıç), gelişen (olgunluk ya da dönüşüm) ve ölen (çöküş ya da düşüş) organizmalar olarak düşünülmektedir (Balc1, 2003).

Morgan (1998) organizma metaforunun dayandığı temel yaklaşımları; neoklasik yönetim kuramları, sistem kuramları, durumsallık kuramı, nüfus (popülasyon) ekolojisi ve örgütsel ekoloji kuramlarıyla ifade etmektedir. Bu kapsamda eğitim örgütlerini organizma metaforu kapsamında değerlendirmeden önce bu metaforun dayandığı kuramları inceleyerek metaforun güçlü ve zayıf yönlerini ortaya koymakta fayda vardir. 


\subsection{Neoklasik (Davranışsal) Yönetim Kuramları}

Neoklasik Yönetim Kuramı'nın en önemli özelliği, Klasik Yönetim Kuramı ile eksik bırakılan insan unsurunun inceleme konusu yapılmasıdır. Bu kuram, Klasik Yönetim Kuramı'na yeni kavramlar ekleyerek kuramın gelişmesine katkıda bulunmuştur. Bu yaklaşım, Klasik Kuram'ın ekonomik rasyonellik anlayışına dayanmakla birlikte buna yeni bir boyut olan insanın tatmin olma ögesini de eklemiștir (Ross ve Murdick, 2002). Neoklasik Yönetim Kuramı, aslında temel olarak Klasik Yönetim Kuramı'nın kavram ve ilkelerine dayanmaktadır. Ancak neoklasik düşüncede, insan ilişkileri yaklaşımının da etkisi ile bu kavram ve ilkeler yumuşatılarak geliştirilmiştir (Baransel, 1993). Başka bir ifadeyle, neoklasik yönetim düşüncesinin, insan ilişkileri yaklaşımı ile klasik yönetim düşüncesinin karışımından meydana geldiğini ve bu iki görüşü ortak noktada buluşturan bir düşünce sistemi olduğunu söylemek mümkündür.

Elton Mayo, Douglas McGregor, Abraham Maslow ve Chris Argyris gibi pek çok kuramc1 Neoklasik yönetim kuramının gelişmesinde katkı sağlamıştır (Koçel, 2005). Aşağıda bu kuramın doğuş ve gelişmesine öncülük eden kuramcıların davranışsal yaklaşıma yönelik odaklandıkları önemli konular üzerinde durularak davranışçı ekolü temsil eden çalışmaların katkılarından bahsedilmiştir.

\subsubsection{Hawthorne Araştırmaları}

Neoklasik yaklaşımın ortaya çıkışında Hawthorne deneylerinin yadsınamaz bir önemi vardır. Hawthorne araştırmaları Elton Mayo ve arkadaşları tarafından Western Elektrik Şirketi'ne ait bir fabrikada yürütülmüştür. Beş yıl süren bu araştırmalar, yönetim ve örgüt konusuna davranışsal açıdan yaklaşmanın başlangıcı olarak kabul edilmiştir (Şimşek ve Çelik, 2009).

Hawthorne araştırmaları, klasik kuramın bir uygulaması olarak başlamakla birlikte araştırmalardan elde edilen sonuçlar yeni bir yaklaşımın ortaya çıkmasına sebep olmuştur. Araştırmacılar ilk etapta fabrikanın 1sıtılması, fiziksel yerleşim düzeni, ş̧ıklandırılması ve işçilerin yorgunluğu gibi etkenlerin verimlilik üzerindeki etkilerini araştırmak üzere çalışmalara başlamışlardır. Yapılan deneyler ve araştırma sonuçları, bazen iyileştirmelere rağmen verimliliğin değişmediğini bazen de herhangi bir iyileştirme yapılmadığı halde verimliliğin arttığını göstermiştir. Buradan yola çıkarak araştırmacılar fiziksel faktörler yerine sosyal faktörler üzerine odaklanmışlardır. $\mathrm{Bu}$ aşamada verimlilikteki artışın sadece işçilerin tatminleri, motivasyonları, birbirleriyle ilişkileri ve yönetim tarafindan uygulanan gözetim şekli gibi psiko-sosyal faktörlerle açılanabileceği sonucuna varmışlardır (Koçel, 2005).

Hawthorne araştırmaları, işveren-işçi ilişkilerinin o tarihe kadar ihmal edilmiş birçok özelliğini de ortaya koyarak yönetim örgütlerinin dikkatini çekmiştir. Bu araştırmalarda informal örgüt yapısı ve grup dinamikleri konularında sistemli çalışmalar yapılmıştır. Yapılan araştırmalarda, çalışma şartları kontrol altına alınsa bile çalışanların bu kontrolün dışında etkileşimde bulundukları görülmüştür (Bursalıoğlu, 2014). Örgütte verimin ancak formel yapı ve kanallar vasıtasıyla yapılan etkileşim sonucunda gerçekleşeceği yönündeki yaygın görüşün aksine; Mayo ve arkadaşları, informal grup yapılarının yönetim amaçlarını gerçekleştirmedeki önemine vurgu yapmışlardır (Robert, 1968). Neoklasik yönetim kuramcılar, çalışanın bir grubun üyesi olduğunu hissettiği ölçüde tatmin olacağını ve bunun sonucunda da daha verimli çalışıp üretkenliğini arttıracağını belirtmişlerdir. Bu nedenle grup kavramının işini bilen yönetimler için çok önemli olduğunu savunmuşlardır (Şimşek ve Çelik, 2009). Balcı'ya (2005) göre, bu araştırmalar sonunda grup oluşturma ve örgüt yöneticilerinin davranışlarındaki olumlu gelişmelerin sürekli verim artışını sağladığı ortaya konulmuştur. Bu durum alanyazına "Hawthorne Etkisi" olarak geçmiştir.

\subsubsection{Maslow'un İhtiyaçlar Hiyerarşisi Kuramı}

İnsan ihtiyaçlarını ilk kez bilimsel bir şekilde değerlendirerek araştıran ve motivasyon konusuna bu bağlamda 1şık tutan araştırmacı Maslow'dur (Eren, 2001). Maslow, öncelikle bu ihtiyaçları önemlilik düzeylerine göre hiyerarşik bir yapıda ele almaya ve sonrasında bu ihtiyaçların çözülebilmesine hizmet edecek örgütsel araçları saptamaya çalışmıştır (Can, Kavuncubaşı ve Yıldırım, 2009). 
Maslow'un beş basamakta sınıflandırmış olduğu temel ihtiyaçlar "fizyolojik ihtiyaçlar", "güvenlik ihtiyacı", "ait olma ve sevgi ihtiyacı", "saygı görme ihtiyacı" ve son olarak "kendini gerçekleştirme ihtiyacı" şeklinde sıralanmaktadır. Buna göre, fizyolojik ihtiyaçlar bireyin hayatının devamlılı̆̆ için gerekli olan beslenme, barınma ve uyuma gibi en temel ihtiyaçlarıdır. Fizyolojik ihtiyacı giderilen bireyin güvende olma ihtiyacının karşılanması gereklidir. Farklı bir ifadeyle, fizyolojik ihtiyaçları karşılanan birey, bir sonraki aşamada fiziksel, ekonomik, sosyal ve siyasi açıdan güvende olma ihtiyacının karşılanmasını beklemektedir. Fizyolojik ve güvenlik ihtiyaçları giderilen bireyin ait olma ve sevgi ihtiyacının giderilmesi gerekmektedir. Bu ihtiyaçların giderilmesi de herhangi bir gruba ait olma, sevme, sevilme ve arkadaş edinme gibi toplumsal ihtiyaçların karşılanmasıyla mümkündür. Maslow'un ihtiyaçlar hiyerarşisine göre, fizyolojik, güvenlik ile sevgi ve ait olma ihtiyaçları karşılanan bireyin bir sonraki aşamada saygı görme ihtiyacı ortaya çıkmaktadır. Bu aşamada, birey diğer insanlar tarafindan takdir edilmeyi ve kendisine değer verilmesini beklemektedir. Alt basamaklarda ihtiyaçları karşılanan birey, son basamakta kendini gerçekleştirerek başarmak istemektedir. Bu aşamada birey, kendi potansiyelinin en üst noktasına ulaşmaya çalışmaktadır (Maslow, 1970).

İhtiyaçlar hiyerarşisi kuramına göre, yukarıda bahsi geçen ihtiyaçlar sırayla giderilmelidir. Diğer bir ifadeyle, alt basamaktaki ihtiyaçlar giderildikten sonra bir üst basamaktaki ihtiyaç karşılanmaya çalışılmalıdır (Çetinkanat, 2000). Bu kurama göre, herhangi bir basamaktaki ihtiyaç karşılanmadan farklı bir basamaktaki ihtiyacın düşünülmesi imkansızdır. Örgüt açısından değerlendirildiğinde ise bu kuramı benimsemiş yöneticiler, çalışanlarının hangi ihtiyaçlarını gidermek istediklerini iyi analiz edebilmeli ve dolayısıyla çalışanlarını tatmin edecek uygun ortamı onlar için oluşturabilmelidir (Gümüş ve Sezgin, 2012). Bu kapsamda örgüt, çalışanlarının fiziksel ihtiyaçlarını ücret vererek, 1sı, havalandırma, kafeterya hizmetleri gibi temel çalışma şartlarını sağlayarak; güvenlik ihtiyaçlarını güvenli iş ortamı, adil kurallar ve uygulamalar, iş güvencesi, sigorta ve emeklilik planları sağlayarak karşılayabilir. Öte yandan örgüt, çalışan merkezli denetimi ve takım çalışmasını teşvik ederek, spor etkinlikleri ve piknikler gibi grup aktivitelerini destekleyerek çalışanlarının sosyal ihtiyaçlarını karşılayabilir. Bunlarla birlikte, örgütler ödül programları, terfiler ve itibarlı unvanlar yoluyla çalışanlarının saygı ihtiyaçlarını karşılarken; çalışanlarını işe dahil ederek, onlara özgü birtakım becerileri ön plana çıkararak ve kişisel gelişimlerine firsat vererek onların kendilerini gerçekleştirme ihtiyaçlarını da karşılamış olurlar (Lunenburg ve Ornstein, 2013).

\subsubsection{X ve Y Kuramı}

1960 yılında Douglas McGregor çalışanları iki grupta sınıflandırarak X kuramı ve Y kuramı şeklinde adlandırdığı bir yaklaşım ortaya koymuştur (Beck, 2000). Bu yaklaşıma göre, X kuramında insanlar olumsuz davranışlar yansıtırken Y kuramında olumlu davranışlar yansıtmaktadırlar (Robbins, 1989). X kuramına göre insanlar gerçekten çalışmak, kendilerini gelişmek istememektedirler ve dolayısıyla onlar zorlanmalı, üretmeleri için yönlendirilmelidirler (Gülnar, 2007). X kuramına göre, çalışmak insan için zevkli değildir. İnsan örgütsel problemleri çözmede çok az yaratıcılık becerisine sahiptir. Bu nedenle örgütsel amaçlara ulaşmada insanı sıkı denetim ve baskı altına almak gerekir (Hersey ve Blanchard, 1982). X kuramı, örgütte otokratik bir yönetim anlayışını gerektirmektedir. Bu kuramı benimsemiş bir yönetici, klasik kuramın da öngördüğü gibi insanı örgütsel ihtiyaçlara uyan pasif bir öge olarak görecek ve daha otoriter bir davranacaktır (Koçel, 2005). Eren'e (2001) göre, bu kuramda insan basit ekonomik güdülerle hareket eden bir robottan farksızdır.

X kuramına karşılık Y kuramında ise çalışmak insan için dinlenmek ve uyun oynamak kadar doğaldır. Bu nedenle insan, uygun koşullar oluşturularak çalışmak zevkli hale getirildiğinde sorumluluk üstlenmek ister ve öz denetim duygusu geliştirebilir (Hatiboğlu, 1976). Y kuramına göre çalışanlar sorumluluk üstlenmekte, kendilerini yönlendirebilmekte, işlerine karşı ilgili davranmakta ve örgütsel sorunları çözmek için çaba göstermektedir (Beck, 2000). Douglas McGregor'a göre, çalışanları Y kuramına göre değerlendiren yöneticiler, onlara monoton ve can sıkıcı işler yerine daha zevkli, yapmaktan doyum sağlayacakları işler vermeli, onları esnek iş saatleriyle çalıştırmalı ve kararlara katılmaları için desteklemelidirler. Çalışanların sürekli kontrol altında tutularak veya korkutularak işe yöneltilmesinden ziyade onlara yeteneklerini ortaya kayabilecekleri iş ortamlarının sağlanması motivasyonun sağlanmasında önemlidir (Solmuş, 2004). 
Kısaca, X kuramında insan davranışlarını sürekli kontrole tabi tutan bir yönetim anlayışının ve buna paralel olarak söylenenleri tepki göstermeksizin yerine getiren bireylerin olduğu söylenebilir. Buna karş1lık Y kuramında, örgütsel amaçların gerçekleştirilmesinde daha demokratik bir yönetim anlayışının ve sorumluluk alan, öz denetim becerilerine sahip bireylerin varlığından söz edilebilir.

\subsubsection{Olgunluk Kuramı}

Chris Argyris tarafından geliştirilen Olgunluk Kuramı'na göre, insan, bebeklik döneminden olgunluk dönemine kadar bir evre içerisinde gelişimini sürdürmektedir. $\mathrm{Bu}$ gelişim sürecinde insan davranışlarında meydana gelen şu değişimler dikkat çekmektedir (Dinçer ve Fidan, 1996):

- Kişi, her şeyi başkalarından beklemeyip pasif durumdan çıkarak aktif duruma geçmektedir.

- Kişi başkalarına karşı tam bağımlı olmayıp görece bağımsızlığa kavuşmaktadır.

- Sınırlı davranışlardan çok yönlü davranışlara geçilmektedir.

- Değişken, geçici ve yüzeysel ilgilerin yerine daha derin ve daha güçlü ilgiler geliştirilmektedir.

- Sadece şimdiki zamanla kısıtlı olan davranışlar yerini geçmiş ve gelecek zamanla ilgili düşünce ve tecrübelere birakmaktadır.

- Bebeklik dönemlerinde kişi kendisini başkalarından aşağıda görürken; olgunluk döneminde başkalarına eşit ya da daha üstün görmektedir.

- Kişi kendi bilgi ve yeteneklerini tanımaya ve öz denetim becerileri geliştirmeye başlamaktadır.

Argyris'in geliştirdiği Olgunluk Kuramı zamanla örgütlere uyarlanmıştır. Buna göre, örgütler var olan yönetim sistemlerine göre bireyin olgunlaşmasını sağlayabildikleri gibi buna engel de olabilmektedirler. Bu bağlamda, merkeziyetçi ve hiyerarşik yapıdaki örgütlerde bireyler pasif kalmaktalar ve başkalarına bağımlı çalışmaktadırlar. Buna karşılık yatay ve âdemi merkeziyetçi yapıdaki örgütlerde kişiler gelişmişlik düzeyleri yüksek olduğundan daha aktiftirler ve bağımsız çalışma becerilerine sahiptirler. Bununla birlikte, yetki ve sorumluluk devrinin olduğu bu örgütlerde bireyler daha yüksek performans göstermektedirler (Dinçer ve Fidan, 1996). Benzer şekilde, Nayır (2008) da merkeziyetçi ve hiyerarşik yapıdaki klasik örgütlerde, işlerin önceden belirlenmesinin rutine yol açtığını ve bu durumun çalışanların çevreleri üzerindeki kontrol gücünü azaltarak onları pasif ve bağımlı hale getirdiğini belirtmektedir.

\subsection{5. Çift Faktör Kuramı}

Herzberg'in çift faktör kuramı, çalışan motivasyonunun sağlanmasında motive edici ve hijyen şeklinde iki ana faktör ortaya koymaktadır (Breif, 1998; Akt. Köroğlu, 2011). Bu faktörler, bireyleri doyuma ulaştıran güdüleyici (motive edici) faktörler ile doyumsuzluğa sebebiyet veren koruyucu (hijyen) faktörler şeklinde de isimlendirilmektedir. Hijyen faktörleri, çalışana motive olmadan önce doyum sağlaması için gerekli olan iş gerekleri olarak bilinmektedir (Crompton, 2003). Herzberg'e göre hijyen faktörleri iş doyumunu sağlamamanın yanı sıra iş doyumsuzluğunu önlemektedir (İncir, 1990). Motive edici faktörler ise bireyin içsel ihtiyaçlarını doyurduğundan çalışanda bağlılık ve istek oluşturmakta, çalışanın işiyle ilgili olumlu tutum geliştirmesine sebep olmaktadır (Tietjen ve Myers, 1998). Hijyen faktörleri; yönetim, denetim, arkadaşlık ilişkileri, çalışma koşulları ve ücret gibi işin dışsal özellikleriyle ilgili faktörlerdir. Motive edici faktörler ise işin kendisi, sorumluluk ve ilerleme, başarı ve tanınma gibi işin içsel özellikleriyle ilgili faktörlerdir (Koçel, 2001).

Yönetim açısından değerlendirildiğinde hijyen faktörleri, bir örgütte bulunması gereken asgari düzeydeki faktörlerdir. Bu faktörlerin varlığı motivasyonu sağlamak için gerekli olan ortamı yaratmaktadır. Motivasyon ise motive edici faktörler sağlandığı takdirde gerçekleşmektedir. Hijyen faktörlerini sağlamadan tek başına motive edici faktörleri sağlamak, çalışanı motive etmede yararlı olmayacaktır. Bir başka ifadeyle, hijyen faktörlerinin sağlanmış olması çalışanların örgüt veya içinde bulundukları grup hakkında olumlu düşünmelerine neden olmakta ancak motivasyonlarına önemli bir katk1 sağlamamaktadır. Motivasyon ancak motive edici faktörler sağlandığı zaman gerçekleşmektedir. Manevi nitelik taşıyan bu faktörler, bireylerin yaptıkları işi severek yapmalarını sağlamakta ve onları çalışmak için özendirmektedir (Balçık, 2002). 


\subsection{Sistem Kuramı}

Sistem kuramı tek başına yeni bir disiplin olmaktan ziyade belirli durumların, olayların ve gelişmelerin araştırılmasında başvurulan bir düşünce biçimi, bir yöntem veya bir yönetim felsefesi şeklinde düşünülebilir. Bu yaklaşımı oluşturan "sistem" kavramı ise belirli alt birimlerden meydana gelen, bu birimler arasında belirli ilişkileri olan ve bu birimlerin dış çevre ile ilişkisi olan bir bütün olarak tanımlanabilir (Eren, 2001). Koçel'e (2005) göre, sistem yaklaşımını diğer yaklaşımlardan ayıran en önemli özellik, bütünü oluşturan bütün parçaların kendilerine has çalışmalarının bulunması ancak her birinin etkinliğinin bir diğeriyle bağlantılı olmasıdır. Farklı bir ifadeyle, sistem yaklaşımı, bütünü meydana getiren parçaları ve bu parçaların birbirleriyle olan ilişkilerini birlikte incelemektedir. Yönetim açısından sistem yaklaşımı ise örgütü çeşitli amaçlar, süreçler ve parçalardan meydana gelen bir bütün olarak değerlendirmektedir. Örgütsel sistemi oluşturan parçalara insan unsuru, makinalar, maddi kaynaklar, formel yetki ilişkileri, görevler ve informel gruplar örnek olarak verilebilir. Bu parçalar örgütün amaçlarını gerçekleştirmek için iletişim ve karar verme süreçleri ile birbirine bağlanmıştır (Koçel, 2005).

Sistem yaklaşımı, genel sistem, açık sistem ve sosyal sistem olmak üzere üç boyuttan oluşmaktadır. Genel sistem yaklaşımında, bir bütünü oluşturan parça ve değişkenlerin karşılıklı ilişki ve bağımlılıkları üzerinde durulmaktadır. Açık sistem yaklaşımı, örgütün içinde bulunduğu çevre ile karşılıklı alış-veriş, girdi-çıktı, ilişki ve etkileşimler üzerinde durmaktadır. Sosyal sistem yaklaşımında ise örgüt sosyal bir grup olarak görülmekte ve toplumsal ortamda davranışları belirleyen normlar ve değerler üzerine odaklanılmaktadır (Altınöz, 2009). Bu çalışmada da sistem yaklaşımı, Genel Sistem Kuramı, Açık Sistem Kuramı ve Sosyal Sistem Kuramı başlıkları altında incelenmektedir.

\subsubsection{Genel Sistem Kuramı}

İlk defa 1930'lu yıllarda Ludwig von Bertalanffy tarafından ortaya atılmış ve daha sonra diğer kuramcılar tarafından geliştirilmiş olan Genel Sistem Kuramı örgütü organizmaya benzetmektedir. Buna göre, örgüt birbirine bağlı yap1 ve görevlerden oluşan bir sistemdir ve bu yönüyle benzer bir mekanizmaya sahip organizmaya benzetilmektedir. Öyle ki organizma da birbirine bağlı yapı ve işlevler bütününden oluşmaktadır (Memduhoğlu, 2010).

Genel sistem kuramının asıl amacının, bilimler arası iş birliği sağlamada sistemli bir çerçeve kurmak olduğu söylenebilir. Bursalığlu'na (2014) göre, farklı bilimlere uyum sağlayabilecek genel bir sistem kuramı geliştirebilmenin iki yolu vardır. Bunlardan ilki, bu bilimlerin tümüne yönelik ortak olayları bulmak ve bu olaylar çerçevesinde genel bir model ortaya koymaktır. İkinci yol ise bu bilimlerdeki temel sistemleri basitten karmaşığa gidecek şekilde belirli bir hiyerarşik yapıda dokuzlu bir sınıflandırmaya tabi tutmaktır. Bu sınıflama modeli Kenneth Boulding tarafindan geliştirilmiş olup modelde yer alan dokuz basamak şu şekilde sıralanmaktadır (Boulding, 1956):

1. Statik yapı şeklindeki sistemler (binalar, masa ve sandalye)

2. Basit dinamik sistemler (güneş sistemi, yıldız sistemleri, saatlerin çalışması vb.)

3. Dengeyi koruma bakımından kendi kendini otomatik olarak ayarlayabilen kontrol mekanizmalı sistem (makineli tüfekler, termostat vb.)

4. Kendini koruyan ve çevre ile etkileşim halinde olan açık sistemler (canlı hücreler)

5. Çevresiyle etkileşim halinde olan ancak hareketli olmayan bitki sistemi

6. Çevresiyle etkileşim halinde ve bununla birlikte artan bir hareketliliğe sahip olan hayvan sistemi

7. Hareketlilik, çevre ile etkileşim ve kendinin farkında olma gibi özelliklerinin yanı sıra dil ve sembol kullanarak fiziksel çevrenin sınırları dışında da aktif olan insan sistemi

8. Ordu, devlet, millet, işletme, okul, aile ve arkadaş grubu gibi insan gruplarının meydana getirdiği sosyal sistemler

9. Kaçınılmaz bilinmeyenler ve nedeni tam izah edilemeyen olayları konu edinen fizik ötesi sistemler

\subsubsection{Açık Sistem Kuramı}

Açık Sistem Kuramı, birçok kuramda ihmal edilen örgüt-çevre etkileşimini ön plana sürmektedir. Bu kuramdan önce, sosyal bilimciler, sosyal yapıları fizik kanunlarına göre kapalı sistem olarak 
görmüşlerdir. Bu kuramı benimseyen biyologlar ise örgütleri açık sistemler olarak değerlendirmişlerdir (Bursalığlu, 2014). Bu bağlamda, örgütü anlamaya yönelik Katz ve Kahn, çıktıdan bir kısmının yeniden girdi olarak sisteme girdiği ve çevre ile sürekli etkileşime dayanan kavramsal bir model önermişlerdir. Katz ve Kahn'ın yaklaşımında; büyük bir sistem içerisinde jenerik alt sistemler (üretim/teknik sistemi, destek sistemi, yaşatma sistemi, uyum sistemi ve yönetsel sistem) bulunmaktadır. Üretim alt sistemi, sistemin temel işlevi olan dönüşümle uğraşmaktadır (eğitim, sağlık vb.). Destek alt sistemleri, çevreyle geçişleri yapmaktadırlar (girdi sağlama, çıktı ihracı, alım, satım etkinlikleri). Yaşatma alt sistemi, doğrudan dönüşümle ilgilenmemekte ancak yapılan işle ilgili destek sağlamaktadır (personelin seçilmesi, yerleştirilmesi, ödüllendirilmesi, kaynak ayırma). Uyum alt sistemi, çevredeki değişme ve gelişmelerle ilgilenerek bunları örgüte bildirmektedir (ürün araştırma, pazar araştırma, araştırma-geliştirme ve uzun dönemli planlama etkinlikleri). Yönetsel alt sistemler, toplam sistemlerin alt sistemlerini kontrol, koordine ve yönlendirmeleri için gerekli örgütlü eylemleri (düzenleyici mekanizmalar ve yetkilendirme) yönetmektedir (Balc1, 2000).

Açık sistemler çevreden aldığı girdileri (insan, bilgi, enerji vb.) işleyerek belli bir değişim/dönüşüm süreci (üretim ve pazarlama etkinlikleri, yönetim süreçleri vb.) gerçekleştirmekte ve sonuçta çevreye birtakım çıktılar (ürünler, hizmetler vb.) sunmaktadır. Bu çıktıların bir kısmı, sistem için yeniden girdi olabilmektedir. Ayrıca, açık sistem modelinde çıktıların bir kısmı atık ta olabilmektedir. Sistemin çok fazla atık üretmesi, amacına ulaşmasını engellemekte ve sistem bu durumda enerji kaybetmektedir. Sistemin enerji kaybetmesi entropi veya güç yitimi kavramlarıyla açıklanmaktadır (Yalçınkaya, 2002). Rifkin ve Howard'a göre (1992), entropi sistemde oluşan dengenin bozulmasıyla açıklanmaktadır. Bu durumda sistem dışarıdan enerji, ham madde ve bilgi alamaz hale gelmekte ve dolayısıyla bozulmakta ve çökmektedir. Sistemlerin hiçbiri bunu istemese dahi ileride bu durumla karşılaşma olasılıkları bulunmaktadır. Kapalı sistemler çevreye kapalı olduklarından entropi ile karşılaşmaları açık sistemlere görece daha çabuk ve fazla olmaktadır (Akt. Ayhan, 2010). Buna karşılık; açık sistem olarak örgütler, entropi ile karşılaşmamak için olumsuz entropi kazanabilirler. Farklı bir ifadeyle, bu örgütler, çevreden tükettiklerinden daha çok enerjiyi alıp depolayabilir ve bu enerjiyi bunalımlı zamanlarında kullanarak yıkılmaktan korunabilirler (Can, 1999).

\subsubsection{Sosyal Sistem Kuramı}

Sosyal Sistem Kuramı'nın öncülüğünü yapan Talcott Parsons, toplumu bir organizmaya benzetmektedir. $\mathrm{Bu}$ kurama göre, sosyal sistem birbirleriyle işlevsel açıdan bağlantılı alt sistemlerden oluşmaktadır. $\mathrm{Bu}$ sistemde birey ve toplum aktördür ve her aktörün işlevsel bir rolü bulunmaktadır (Özdemir, 2001). Bu açıdan bakıldığında, sosyal sistemlerin temelinde bütünleşmeyi sağlayan roller, normlar ve değerler bulunmaktadır. Belirli roller üstlenen üyelerin uygun davranışları neticesinde ortaya çıkan kalıplaşmış beklentiler, sosyal sistemi yaratmaktadır (Bursalıŏlu, 2014).

Parsons'a göre sosyal sistem birbirleriyle fonksiyonel bağıntılı ve etki-tepki ilişkisi içerisinde çeşitli kurumların (hukuk, ekonomi ve eğitim gibi) birbiriyle uyumlu ilişkisinden oluşmaktadır. Bu kurumların her biri sistemin devamlılığı için olumlu katkı sağlamaktadır (Munch, 1994). Bu bağlamda, sosyal sistemlerin temel dört temel fonksiyonu bulunmaktadır. "AGIL" modeli olarak da bilinen bu fonksiyonlar aşağıdaki gibi sıralanmaktadır (Özkalp, 2013, s. 106):

Uyum fonksiyonu. Sosyal sistem çevresini tanıyarak değişimlere ayak uydurmalı ve gereken uyumu gösterebilmelidir.

Amaca ulaşma fonksiyonu. Sosyal sistem amaçları belirlemenin yanı sıra amaçlara erişebilmek için belirli stratejileri de oluşturmalıdır.

Bütünleşme fonksiyonu. Sosyal sistemi oluşturan parçaların birbirleriyle olan bağlantıları anlaşılmalı, bu parçalar örgütlenmeli ve eşgüdümlü faaliyetlerde bulunmalıdır.

Meşruluk fonksiyonu. Yaşanılan çevre içerisinde sosyal sistemin devamlılığını sürdürebilmesi için toplumun bütünü tarafından kabul görmesi ve uygun görülmesi gerekmektedir. 


\subsection{Durumsallık Kuramı}

Durumsallık yaklaşımı, klasik yaklaşımın ve neoklasik yaklaşımın eksikliklerini gidermek ve sistem yaklaşımının genel ve soyut özelliklerinden kaynaklanan uygulamadaki güçlükleri ortadan kaldırmak amacıyla 1970'lerden sonra gelişmeye başlamış bir yaklaşımdır. Bu yaklaşımına göre, örgütlerin etkili olabilmesinde belirli ilkelerin uygulanması değil; bu ilkeler ile iç ve dış çevre koşulları arasındaki uyumun sağlanması önemlidir. Bu yaklaşım, her yerde ve her zaman geçerli olan örgüt yapısından söz edilemeyeceğini, örgüt ile ilgili her şeyin zamana, duruma ve mekâna göre değişim gösterebileceğini belirtmektedir (Dinçer, 1992).

Wooton'a (1977) göre durumsallık yaklaşımı, tek bir en iyi yolun olduğu düşüncesinin yerine; örgütün içinde bulunduğu durumun özelliklerine göre çeşitli uygun stratejiler seçilebileceği görüşünü benimsemekte ve bunun yanı sıra, çevresel koşulların sürekli değişim halinde olduğu ve değişimin yönetsel süreçlerin bir parçası olduğu düşüncesini de ortaya koymaktadır. Morgan (1998) ise durumsallık yaklaşımına göre örgütleri açık sistemler olarak değerlendirmektedir. Buna göre, yönetimin öncelikli kaygısı örgüt ve çevre arasında uyumun sağlanması olmalıdır. Örgütlerde iç gereksinimlerin karşılanıp dengelenmesi ve çevresel koşullara uyumun sağlanabilmesi için dikkatli bir yönetim gereklidir. Yerine getirilecek görevin veya çevrenin durumu örgütlenmenin ne şekilde yapılacağını belirler. Farklı görevler aynı örgüt içinde farklı yaklaşımlar gerektirebilir. Çevrenin türüne göre örgüt türleri de değişebilir.

Kısaca, durumsallık yaklaşımına göre dünyanın her yerinde geçerli olabilecek tek bir örgüt yapısı ve yönetim felsefesi oluşturmanın mümkün olmadığı söylenebilir. Sürekli değişen bir çevrede örgütlerin sabit ilkelere bağlı kalmak yerine; içinde faaliyet gösterdikleri çevrenin koşullarına ayak uydurmaları gerekmektedir. Bu durum, bir örgütün mevcut durumu ve çevre koşulları analiz edilmeden tepeden inme bir davranış ile örgüt yapısının ve yönetim anlayışının oluşturulamayacağı şeklinde de ifade edilebilir.

\subsection{Nüfus (Populasyon) Ekolojisi ve Örgütsel Ekoloji Kuramı}

Hannan ve Freeman (1977) Nüfus Ekolojisi Kuramı'nı, yaygın bir görüş olan örgütlerin varlıklarının devamlılığı için çevrelerine uyum sağlamaları gerektiği anlayışına alternatif bir görüş olarak geliştirilmiştir. Bu kuram, örgütlerin varllğını ve çeşitliliğini Darwin'in "doğal seçilim” görüşüne göre açıklamaktadır (Hannan ve Freeman, 1977). Darwin'in Evrim Kuramı'nda belirttiği gibi doğal seçilim sürecinde ayakta kalmaya çalışan örgütler, rekabetle karşı karşıyadır ve kaynak darlığından dolayı ancak en sağlam olanlar ayakta kalabilmektedir. Burada önemli olan örgütlerin çeşitli şekillerde kaynak elde ederek rakiplerini geçmeleri ve 'seçilmeleridir' (Morgan, 1998).

Nüfus Ekolojisi Kuramı, örgütlerin çevresel şartlara göre değişmek için çaba sarf etmediklerini iddia etmekte ve bunu "yapısal atalet" kavramıyla açıklamaktadır. Buna göre, örgütlerin uyum sağlamak için değişmek gibi bir çabası yoktur. Örgütler önce çeşitlenmekte ve sonrasında çevresel şartlara uyum sağlayanlar varlıklarını devam ettirmekte, diğerleri yok olmaktadır (Hannan ve Freeman, 1977). Bu kuram bir örgütün varlığını nasıl devam ettirdiğinden ziyade aynı kaynak havuzundan yararlanan tüm örgütlerin nasıl başarılı olduklarıyla ilgilenmektedir (Robbins, 1990). Nüfus Ekoloji Kuramı, çevreye uyum sağlayan her örgütten ziyade uyum sağlayan örgütler arasından güçlü olanları seçmekte, diğerlerini elemektedir ve bu yönüyle de eleştirilmektedir (Dinçer, 1998).

Nüfus Ekolojisi Kuramı örgütlerin rekabet halinde olmalarının yanı sıra iş birliği de yapabilecekleri gerçeğini göz ardı etmesinden ve yönetsel süreçlere gereken önemi vermemesinden dolayı da eleştirilmiştir. Bu nedenle Örgütsel Ekoloji Kuramı olarak da bilinen daha iyimser bir örgüt yapısı ortaya çıkmıştır. Örgütsel Ekoloji Kuramı'nda, Nüfus Ekolojisi Kuramı'nın aksine örgüt ve çevre birlikte düşünülmektedir. Örgüt, tüm çevresi ile evrim sürecine girdiğinden değişim ve adaptasyon süreci de eş zamanlı ve birlikte geçirilmektedir. Dolayısıyla hem örgüt hem de örgütün çevresi, evrim yoluyla tamamen değişmektedir. Bu durum, örgütlerin, çevrelerindeki diğer örgütlerle uyum içerisinde davranmalarını da gerektirmektedir (Morgan, 1998). Örgütsel Ekoloji Kuramı'nda sistemin devamlılığı örgütün çevreyle ilişkisine bağlıdır. Bu kurama göre çevresel kaynaklar için yarışan bütün faktörler iç içe geçmiştir ve birbirleriyle karşıllklı ilişki içerisindedir (Li, 2012; Akt. Bakioğlu, 2017). Kısacası, Örgütsel Ekoloji Kuramı'nda iş birliği önemlidir. Örgütler ancak diğer örgütlerle uyum ve iş birliği içerisinde olduklarında ayakta kalabilir ve geleceklerini oluşturabilirler. 


\section{ORGANIZMA METAFORUNUN GÜÇLÜ VE ZAYIF YÖNLERİ}

Organizma metaforu kapsamında açıklanan kuramlar dikkate alındığında her kuramın kendine özgü güçlü ve zayıf yönlerinin olduğu görülmektedir. Bu bağlamda, örgütleri organizmaya benzeterek açıklayan organizma metaforunun da bir takım güçlü ve zayıf yönleri bulunmaktadır. Morgan (1998, s. 80) organizma metaforunun güçlü yönlerini şu şekilde açıklamaktadır:

- Örgütlerin en güçlü yönü çevreleriyle olan güçlü ilişkileridir.

- İnsan ve örgüt ihtiyaçları önemlidir. Örgüt ihtiyaçları da insan ihtiyaçlarında olduğu gibi sürekli ve aşamalıdır. Örgütlerin ayakta kalabilmesi için bu ihtiyaçların karşılanması gerekmektedir.

- Farklı örgüt türlerinde farklı örgütlenmeler vardır. Bu durum, yöneticilerin ve örgüt tasarımıyla ilgili kişilerin daima seçme hakkının olduğunu ve örgütün etkinliğinin tercihin niteliğine göre değiştiğini göstermektedir.

- Organizma metaforunda yenilenme süreci vardır. Organik örgüt biçimlerinin esnek ve dinamik yapıda olması örgütün yenilenme sürecini kolaylaştırmaktadır.

Görüldügü üzere örgütün esnek ve dinamik bir yapıda olması, örgüt ve çevre arasındaki uyum, yöneticilere farklı örgütlenmeler arasından seçim yapabilme firsatının verilmesi, çalışanların ve örgütün ihtiyaçlarının karşılanması organizma metaforunun güçlü yönlerini oluşturmaktadır. Bununla birlikte Morgan (1998, s. 82) organizma metaforunun zayıf yönleri aşağıdaki gibi ele almaktadır:

- Organizmalarda "ișlevsel birlik" vardır. Yani alt sistemlerin birbiriyle uyumu söz konusudur. Bu ilişki kapsamında sistemin her öğesi normal koşullarda diğer öğeler için çalışmaktadır. Ancak çoğu örgütte böyle bir bütünlük söz konusu değildir. Örgütlerde farklı öğelerin veya birimlerin organizmalardaki gibi uyumlu çalışması genellikle istisnadır. Bu durum, örgütte bölünmelere ve çatışmalara neden olmaktadır.

- Organizma metaforu, örgütleri ve çevrelerini aşırı somut bir biçimde görmemize yol açmaktadır. Örgüt, çevresi ile etkileşim halindedir ancak bu etkileşimin sınırları iyi belirlenmezse bu durum örgütler için olumsuz sonuçlar doğurabilmektedir. Örgütlerin etkili görünen yönleri bazen sistem içerisinde örgütün zayıf yönü olabilmektedir.

Organizma metaforunun zayıf yönleri dikkate alındığında, biyolojik organizmalarda var olan işlevsel birliği örgüt içerisinde sağlamadaki yaşanılan güçlüğün metaforun en zayıf yönü olduğu görülmektedir. $\mathrm{Bu}$ durum, organizma metaforunda örgütteki farklı değer, norm ve rollere sahip insanların bunları bir tarafa bırakıp tamamen kendilerini örgüte adamalarının zor olduğu şeklinde de ifade edilebilir.

\section{EĞITIM ÖRGÜTLERINNDE ORGANIZMA METAFORU}

Eğitim örgütleri organizma metaforu kapsamında değerlendirildiğinde, genel olarak öncelikle bir okulda birbirleriyle sürekli etkileşim halinde olan öğrenci, veli, öğretmen, yönetici ve denetmen gibi paydaşların arasındaki organik bağlllık akla gelmekte ve sonrasında okulların çevresi ile olan ilişkisi dikkat çekmektedir. Okulları organizma metaforu kapsamında ele alarak detaylı bir şekilde incelemek için bu metaforu açıklamada yararlandığımız kuramlar (Neoklasik Yönetim Kuramı, Sistem Kuramı, Durumsallık Kuramı, Nüfus Ekolojisi ve Örgütsel Ekoloji Kuramı) 1şı̆̆ında bir değerlendirme yapılması daha doğru olacaktır.

Neoklasik yönetim yaklaşımı kapsamında incelenen tüm kuramlarda örgütte insana yönelik 'teknik' bakışın yerini 'sosyal ve psikolojik' bakışa bıraktığı görülmektedir. $\mathrm{Bu}$ açıdan bakıldığında, bu yaklaşımla birlikte klasik yönetim yaklaşımında ihmal edilen insan unsuruna odaklanmanın okullara demokratik bir yönetim anlayışını getirdiği söylenebilir. Bursalığlu'na (2014) göre, neoklasik yaklaşımla birlikte demokratik örgüt olarak kabul edilen okullar, insan ilişkileriyle ilgili ilkeleri demokratik yönetim adı altında uygulamaya başlamışlardır. Bu durum, okulların ve öğretmenlerin değerlendirilmesi, eğitim programları ve personel yönetimi gibi eğitimin birçok alanında fayda sağlamıştır. Neoklasik yaklaşımla birlikte okul müdürünün üzerindeki değerlendirme sorumluluğu hafifletmiştir. Öğretmenlerin değerlendirilmesinde müfettişlerin görev ve rollerinde önemli yenilikler getirilmiştir. Eğitimde denetimin teknik yanı kadar psikolojik ve sosyal yanı önemsenmiş; denetim 
sürecinde demokratik insan ilişkileri önem kazanmıştır. Öğretmenlerin duygu ve heyecanlarının olduğu kabul edilerek kişilik, davranış, yenilik ve değişme, iletişim ve öğrenme becerileri önem kazanmıştır. Eğitim programlarında, çocuğun hayata uyumu genel amaç olarak benimsenmiş ve okullara öğrenciyi sosyalleştirme görevi verilmiştir. Personel yönetiminde ise çalışanların ihtiyaç ve beklentilerinin örgüt amaçları ile dengelenmesi; çalışanların bilgi ve becerilerinin koordine edilmesi gibi konularda eğitim yöneticilerine yeni roller verilerek onların iyi birer personel yöneticisi olmalarına dikkat çekilmiştir.

Sistem yaklaşımı kapsamında okulların açık toplumsal bir sistem olarak incelenmesi mümkündür. Okul, açık toplumsal bir sistem olarak çevresinden ve bir alt okuldan girdiler almakta ve bunları işledikten sonra üst okullara ve çevreye vermektedir. İnsan (öğrenci, öğretmen, yönetici vb.), bilgi (değerler, amaçlar, ilkeler ve programlar vb.), teknoloji (öğretimsel araç-gereçler, görsel ve işitsel araçlar vb.) ve finansman (bağış, yardım, genel ve özel bütçeden gelen devlet katkıları, döner sermaye vb.) okulun girdileri arasında sayılabilir. Okul bu girdileri yönetim süreçlerinden ve eğitim-öğretim süreçlerinden faydalanarak işlemekte ve çıktıya dönüştürmektedir. Eğitim almış öğrenciler, ürünler (kitap, gazete, dergi vb.), hizmetler (toplantılar-panel, proje vb.) ve para (döner sermaye, vakıf vb.) da okulun çıtıları arasında sayılabilir (Yalçınkaya, 2002). Okulun çıktıları kendisi için tekrar girdi olmakta ve bu dönüşüm sürekli devam etmektedir. Okulun ürettiği çıktılar kendisine yeterli düzeyde dönmediği takdirde entropi (güç yitimi) ortaya çıkmaktadır. Bu nedenle okullar her yıl bir önceki yıldan daha fazla girdi alarak entropiyi azaltmaktadırlar.

Sistem yaklaşımına göre okullar her sistem de olduğu gibi alt sistemlerden oluşmaktadır. Bunlar; eğitim hizmetlerinin yapıldığı üretim alt sistemi, girdi-işleme-çıktı sürecini yürüten alış-veriş alt sistemi, çevre ile ilişkileri düzenleyen uyarlama alt sistemi, okulun güvenliğini sağlayarak ömrünü uzatan yaşatma alt sistemi ve okulu bütün alt sistemleriyle birlikte işleten yönetim alt sistemleridir (Başaran, 1996). Organizma metaforunda önemli bir yere sahip olan çevreye uyum konusu okullarda uyarlama alt sistemleri sayesinde gerçekleşmektedir. Açık sistem ilkelerine göre, okul ve çevrenin birbirinden etkilenmesi, aynı amaçlara yönelik çalışması, birlikte hareket etmesi, birindeki değişimin diğeri tarafindan izlenmesi beklenmektedir. Okul çevresindeki değişmelere yönelik sürekli bilgi sağlayacak ve böylece çevre ile olan dengesini devam ettirecektir. Bu değişmelerden kendi amaçlarıyla örtüşenlere uyum sağlayacak ve amaçlarına aykırı olanları düzeltmeye çalışacaktır (Bursalığlu, 2014).

Durumsallık yaklaşımı açısından bakıldığında okulların mevcut yönetim şekilleri dikkate alınmalıdır. Diğer bir ifadeyle, bu yaklaşımda yöneticinin gelişime, yeniliğe ve değişime açık olması önemlidir. Okul bir örgüt olarak iç ve dış ortamından ayrı ele alınamayacağından yönetici çağa ayak uydurmalı hem kendisini hem de okulu geliştirmeli, içinde bulunduğu koşullara uyum sağlamalıdır. Okulların birbirinden farklı olması, her öğretmenin ya da çalışanın farklı kişiliğe sahip olması, öğrencilerin yaş ve kişisel özelliklerinin farklılık göstermesi gibi hususlarda okul yöneticisinin yaklaşımı önemlidir. Yöneticinin, tüm bu farklılıklara rağmen okul içerisinde uyumlu ve eşgüdümlü bir çalışma ortamının oluş̧urulmasından sorumlu olduğu söylenebilir.

Nüfus Ekolojisi Kuramı açısından okullar değerlendirildiğinde, bu yaklaşımın eğitim örgütleri için geçerli olduğunu söylemek pek mümkün değildir. Eğitimde örgütsel düzeyde okulların sürekli rekabet etmesi ve sadece iyi olanların yaşamlarını devam ettirmesi eğitimin iş birliğine, paylaşıma dayalı yönünün ihmal edilmesine yol açabilir. Bu nedenle, Morgan'ın (1998) daha iyimser bir yaklaşım olarak açıkladığı Örgütsel Ekoloji Kuramı'nın eğitim örgütleri için görece daha uygun olduğu söylenebilir. Bu kurama göre okulların, çevreleriyle ve diğer okullarla yarışmacı bir anlayışla rekabet etmeleri değil; iş birliği içerisinde birlikte hareket etmeleri daha önemlidir.

\section{SONUÇ VE TARTIŞMA}

Organizma metaforu ile örgütler organizmalara benzetilmiştir. Organizma metaforu örgütün bir organizma gibi doğumundan ölümüne kadar değişen koşullara nasıl uyum sağlayabileceğini anlamamıza yardımcı olmaktadır. Organizma çevresine uyum sağlamaya çalışır, uyum sağlayamazsa da yaşayamaz ve ölür. Örgütler de çevreleriyle etkileşim halinde olmaz, gelişmeleri takip etmez ve değişen çevre koşullarına göre kendilerini yenilemezlerse yok olmaya mahkûm olurlar. Organizma metaforunda ayrıca makine metaforunun görmezden geldiği insan unsurunun ve çevresel faktörlerin ön plana çıktığı görülmektedir. 
Organizma metaforu insana yönelik 'teknik' bakışın yerini 'sosyal ve psikolojik' bakışa bıraktığ1 Neoklasik Yönetim Kuramları, örgüt-çevre ilişkisine önem veren Sistem Kuramı, Durumsallık Kuramı, Popülasyon ve Örgütsel Ekoloji Kuramları ile değerlendirilmektedir. Neoklasik yönetim yaklaşımına göre, örgüt içerisinde verimi artırmak için insan ihtiyaçları önemlidir ve bunların karşılanması gerekmektedir. Sistem Kuramı'nda örgüt-çevre ilişkisi üzerinde durulmaktadır. Örgüt çevresinden girdileri alan, işleyen, çevresine çıktı veren ve çevreden aldığı geri besleme ile entropiyi yenerek yaşamını devam ettiren bir sistem olarak ele alınmaktadır. Ayrıca örgüt bir sistem olarak alt sistemlerden meydana gelmekte ve örgütün ayakta kalabilmesi için alt sistemleri arasındaki etkileşimin güçlü olması gerekmektedir. Durumsallık yaklaşımına göre, örgüt ile ilgili her şey mekâna, duruma ve zamana göre değişmektedir. Yani farklı çevrelere göre farklı örgüt tipleri mevcuttur. Popülasyon ekolojisi kuramında rekabet halinde olan örgütlerden güçlü olanlar çevreye uyum sağlamakta ve ayakta kalabilmekte; diğerleri yok olmaktadır. Örgütsel Ekoloji Kuramı'nda ise örgütler ancak diğer örgütlerle uyum ve iş birliği içerisinde olduklarında varlıklarını sürdürebilmektedirler.

Sonuç olarak, organizma metaforu kapsamında ele alınan kuramlar örgütlerin farklı yönlerine vurgu yapsalar da bu kuramların temelde örgüt, insan ve çevreyi bir bütün olarak görme noktasında ortak paydada buluştukları görülmektedir. Dolayısıyla eğitim örgütleri olan okulları da bu kuramların varsayımları açısından değerlendirdiğimizde, insan unsuruna önem veren Neoklasik yaklaşımla birlikte örgütsel amaçlara ulaşmada tüm paydaşların ihtiyaç ve beklentilerini önemseyen bir anlayışın ortaya çıktığı söylenebilir. Bununla birlikte, okulların açık toplumsal bir sistem olarak görüldüğünü ve bu kapsamda alt sistemleri aracılığıyla çevredeki değişimlere uyum sağladıklarını söylemek mümkündür. Ayrıca durumsallık yaklaşımının okullarda yönetsel faaliyetlerin yürütülmesinde önemli bir yere sahip olduğu dikkat çekmektedir. Zira yöneticilere bu konuda çok iş düşmektedir. Yöneticiler hem okul içerisinde çalışanlarına ve öğrencilerine uyumlu bir ortam sağlamaktan hem de çevresel koşullara ayak uydurmaktan sorumludur. Öte yandan, sürekli rekabeti ön gören Nüfus Ekolojisi Kuramı'nın okullara uyarlanması pek mümkün görünmemektedir ancak iş birliğini vurgulayan Örgütsel Ekoloji Kuramı okullar için düşünülebilir. Okulların diğer okullarla ve çevredeki diğer kuruluşlarla iş birliği içerisinde hareket etmesinin değişim ve gelişim açısından yadsınamayacak derecede önemli olduğunu söylemek mümkündür.

Bilgilendirme / Acknowledgement: Bu çalışma Ankara Üniversitesi, Eğitim Yönetimi ve Teftişi doktora programı kapsamında Prof. Dr. Ali BALCI tarafindan yürütülen “Örgüt İmajları” dersinde yazar tarafından sunulmuştur.

\section{KAYNAKÇA}

Altınöz, M. (2009). Öğretmen ve yönetici algılarına göre özel okul yöneticilerinin yönetim yaklaşımları ve uygulama. Yayımlanmamış yüksek lisans Tezi, Maltepe Üniversitesi Sosyal Bilimler Enstitüsü, İstanbul.

Ayhan, U. (2010). Kamu kuruluşlarının yönetiminde sistem yaklaşımının uygulanabilirliği. Polis Bilimleri Dergisi, 12(1), 105-123.

Bakioğlu, A. (2017). Karşılaştırmal eğitim politikalar, göstergeler, bağlamlar. Konya: Eğitim Yayınevi.

Balcı, A. (2005). Eğitim yönetimi terimleri sözlüğü. Ankara: Tek Ağaç Basım Yayım Dağıtım Ltd. Şti.

Balcı, A. (2003). Eğitim örgütlerine yeni bakış açıları: Kuram-araştırma ilişkisi II. Kuram ve Uygulamada Eğitim Yönetimi, 9(33), 26-61.

Balcı, A. (2000). Örgütsel gelişme: Kuram ve uygulama. 2. baskı. Ankara: Pegem A. Yayıncılık.

Balc1, A. (1999). Metaphorical images of school: School perceptions of students, teachers and parents from four selected schools. Yayımlanmamış doktora tezi, Orta Doğu Teknik Üniversitesi, Ankara.

Balçık, B. (2002). İsletme yönetimi. Ankara: Nobel Yayın.

Baransel, A. (1993). Çağdaş yönetim düşüncesinin evrimi. İstanbul: Avcılol Basım Yayım. 
Başaran, İ. E. (1996). Eğitim yönetimi. 5. baskı. Ankara: Yargıcı Matbaası.

Beck, R. C. (2000). Motivation: Theories and principles. 4th Edition. New Jersey: Prentice Hall.

Boulding, K. E. (1956). General systems theory: The sceleton of science. Management Science, 2(3), 197-208.

Bursalıoğlu, Z. (2014). Eğitim yönetiminde teori ve uygulama. 12. Baskı. Ankara: Pegem Yayıncılık.

Can, H. (1999). Organizasyon ve yönetim. 5. Bask1. Ankara: Siyasal Kitabevi.

Can, H., Kavuncubaşı, Ş. ve Yıldırım, S. (2009). İnsan kaynaklarl yönetimi: kamu ve özel kesimde. 6. Baskı. Ankara: Siyasal Kitabevi.

Crompton, J. L. (2003). Adapting Herzberg: A conceptualization of the effects of hygiene and motivator attributes on perceptions of event quality. Journal of Travel Research, 41(3), 305-310.

Çetinkanat, C. (2000). Örgütlerde güdülenme ve iş doyumu. Ankara: Anı Yayıncılık.

Dinçer, Ö. (1998). Stratejik yönetim ve işletme politikası. İstanbul: Beta Basım.

Dinçer, Ö. (1992). Örgüt geliştirme: Teori, uygulama ve teknikler. 1. Baskı. İstanbul: Timaş Basım.

Dinçer, Ö. ve Fidan, Y. (1996). İşletme yönetimi. 1. Bask1. İstanbul: Beta Yayın.

Eren, E. (2001). Örgütsel davranış ve yönetim psikolojisi. 7. Baskı. İstanbul: Beta Basım Yayım Dağıtım A.Ş.

Gülnar, B. (2007). Örgütlerde iletişim ve iş doyumu. İstanbul: Literatürk Yayınları.

Gümüş, S. ve Sezgin, B. (2012). Motivasyonun örgütsel bağllliğa ve performansa etkisi. 1. Bask1. İstanbul: Hiperlink Yayınları.

Hannan, M. T., \& Freeman, J. (1977). The population ecology of organizations. American Journal of Sociology, 83, 929-984.

Hatiboğlu, Z. (1976). Organizasyon: Personel davranışı ve yönetimi. İstanbul: Metler Matbaası.

Hersey, P., \& Blanchard, K. (1982). Management of organizational behavior. New Jersey: Prentice Hall. İncir, G. (1990). Çalışanların iş doyumu üzerine bir inceleme. Ankara: MPM Yayınları.

Koçel, T. (2005). İsletme yöneticiliği. İstanbul: Arıkan Yayınevi.

Koçel, T. (2001). İşletme yöneticiliği, yönetim ve organizasyon, organizasyonlarda davranış klasikmodern-çağdaş ve güncel yaklaşımlar. 8. Baskı. İstanbul: Beta Yayınları.

Köroğlu, Ö. (2011). İş doyumu ve motivasyon düzeylerini etkileyen faktörlerin performansla ilişkisi: Turist rehberleri üzerine bir araştırma. Yayımlanmamış doktora tezi, Balıkesir Üniversitesi Sosyal Bilimler Enstitüsü, Balıkesir.

Lakoff, G., \& Johnson, M. (2005). Metaforlar Hayat, Anlam ve Dil. (Çev. G. Y. Demir). İstanbul: Paradigma.

Lunenburg, F. C., \& Ornstein, A. C. (2013). Eğitim yönetimi. (Çev. Ed. G. Arastaman). Ankara: Nobel Yayınc1lik.

Maslow, A. H. (1970). Motivation and personality. 2. Edition. NewYork: Harper\&Row Publishers.

Memduhoğlu, H. B. (2010). Yönetim düşüncesinin evrimi ve yönetişim. H. B. Memduhoğlu ve K. Yılmaz (ed.) Yönetimde yeni yaklaşımlar. (s.1-29). Ankara: Pegem A. Yayıncılık.

Morgan, G. (1998). Yönetim ve örgüt teorilerinde metafor. (Çev. G. Bulut). İstanbul: MESS Yayın.

Munch, R. (1994). Sociological theory from 1920s to 1960. Chicago: Nelson- Hall Publishers.

Mutlu, E. (2004). Illetişim sözlüğü. Ankara: Bilim ve Sanat Yayınları. 
Nayır, F. (2008). Organizma metaforu. A. Balcı (ed.) Örgüt mecazları (s.19-38). Ankara: Pegem A. Yayınc1lik.

Özdemir, C. (2001). Neofonksiyonalizm. Eskişehir Osmangazi Üniversitesi Sosyal Bilimler Dergisi, 1, 81-90.

Özkalp, E. (2013). Örgütsel davranış. Bursa: Ekin Kitapevi.

Robbins, S. P. (1990). Organization Theory: Structure, design and applications. New Jersey: Prentice Hall.

Robbins, S. P. (1989). Organizational behavior: Concepts, controversies and applications. 4th Edition. New Jersey: Prentice Hall.

Robert, D. (1968). Human relations in administration. New Jersey: Prentice Hall.

Ross, F., \& Murdick R. (2002). People productivity and organizational structure. Contemporary Readings in Organizational Behavior. New York: McGraw Hill.

Solmuş, T. (2004). İş yaşamında duygular ve kişilerarası iliş̧kiler; Psikoloji penceresinden insan kaynakları yönetimi. İstanbul: Beta Yayınları.

Şimşek, Ş. ve Çelik, A. (2009). Yönetim ve organizasyon. Ankara: Pozitif Matbaacıllk.

Şişman, M. (2011). Örgütler ve kültürler. Ankara: Pegem A Yayıncılık.

Tietjen, M. A., \& Myers, R. M. (1998). Motivation and job satisfaction. Management Decision, 36(4), 226-231.

Wooton, L. M. (1977). The mixed blessings of contingency management. Academy of Management Review, 2(3), 431-441.

Yalçınkaya, M. (2002). Açık sistem teorisi ve okula uygulanması. Gazi Üniversitesi Eğitim Fakültesi Dergisi, 22(2), 103-116. 